\title{
NUTRIENT RESPONSES ON EXPOSED MOUNTAIN SUBSOILS
}

\author{
G. A. Dunbar and S. N. Adams" \\ Tussock Grasslands and Mountain Lands Institute, \\ Lincoln College
}

\section{Summary}

The effects of different nutrient combinations on growth of Yorkshire fog and white clover were studied in the glasshouse at Lincoln with subsoils from ten high-altitude sites throughout the South Island. There were outstanding responses by Yorkshire fog to nitrogen and phosphorus in combination, and by white clover to phosphorus on all soils. In the presence of these nutrients substantial responses to magnesium, potassium, and magnesium and potassium in combination were obtained on many soils. Copper, boron and zinc generally gave no benefit, and sulphur and molybdenum produced few marked responses. Lime was beneficial on the more acid soils, but on others depressed growth unless magnesium and potassium were also applied.

\section{INTRODUCTION}

IN MOUNTAIN AREAS throughout the South Island, and particularly on soils derived from greywacke, exposed subsoil horizons and screes are a common feature of the landscape at altitudes of from 1000 to $1500 \mathrm{~m}$ above sea level. On these erosion surfaces at this altitude, natural revegetation is at best an extremely slow process. Experimental work designed to establish ways of hastening vegetation recovery of these areas is comparatively recent in origin (O'Connor, 1967; O'Connor and Lambrechtsen, 1967; Dunbar, 1970; Holloway, 1970). The early work had shown the importance of fertilizers in assisting establishment of berbaceous species on such sites and had given leads to the more useful species (Dunbar, 1971), but the need for some of the less commoniy applied major and minor elements was not clear.

This paper describes two glasshouse trials which examined the effect of several major and minor plant nutrients on growth of Yorkshire fog and white clover on mountain subsoils.

"Present address: Chemical Research Division, Ministry of Agriculture, Queens University, Belfast, Northern Ireland. 


\section{EXPERIMENTAL}

Soil material from the top $15 \mathrm{~cm}$ of an exposed subsoil horizon or scree was collected early in 1966 from ten high-altitude sites throughout the South Island (Fig. 1). The sites were from $840 \mathrm{~m}$ to $1430 \mathrm{~m}$ above sea level. The exposed surface material at these localities consisted of a mixture of $\mathrm{B}$ and $\mathrm{C}$ horizons frequently with pebbles or rock fragments forming an erosion pavement. For simplicity, the materials from each site are referred to here as soils and have been given the name assigned to the collection locality. The original soil sets to which nine of these subsoils

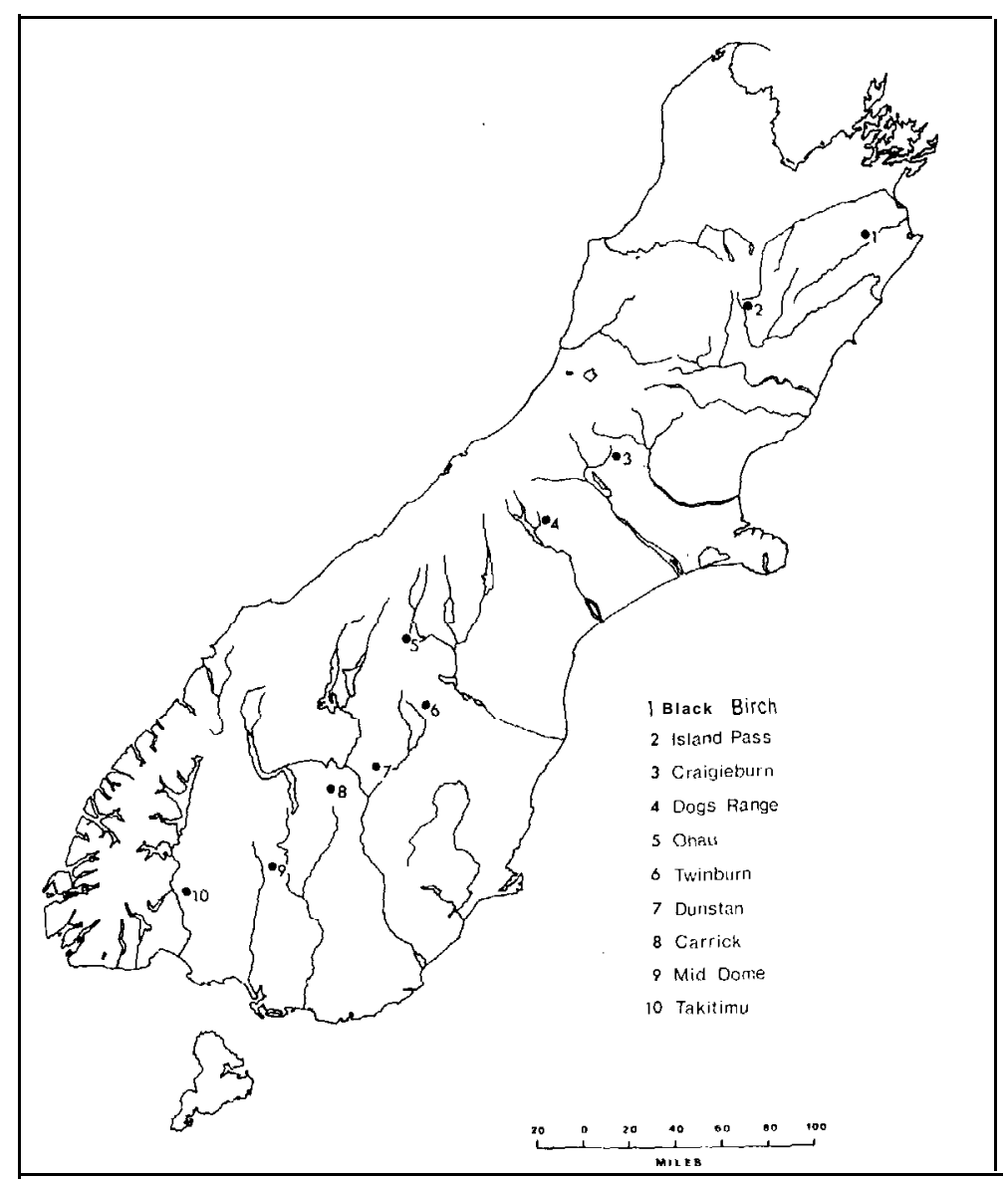

FIG. 1: Sites of experimental soil material. 
belong are classed as yellow-brown earths (N.Z. Soil Bureau, 1968). The soil set for Takitimu site is classed within the brown granular loam and clays to yellow-brown earth intergrade.

Figures for $\mathrm{pH}$, soil quick tests, cation exchange, and exchangeable bases for the less than $2 \mathrm{~mm}$ fraction of these soils are given in Table 1.

TABLE 1: SOIL pH, QUICK TEST RESULTS AND EXCHANGE DATA

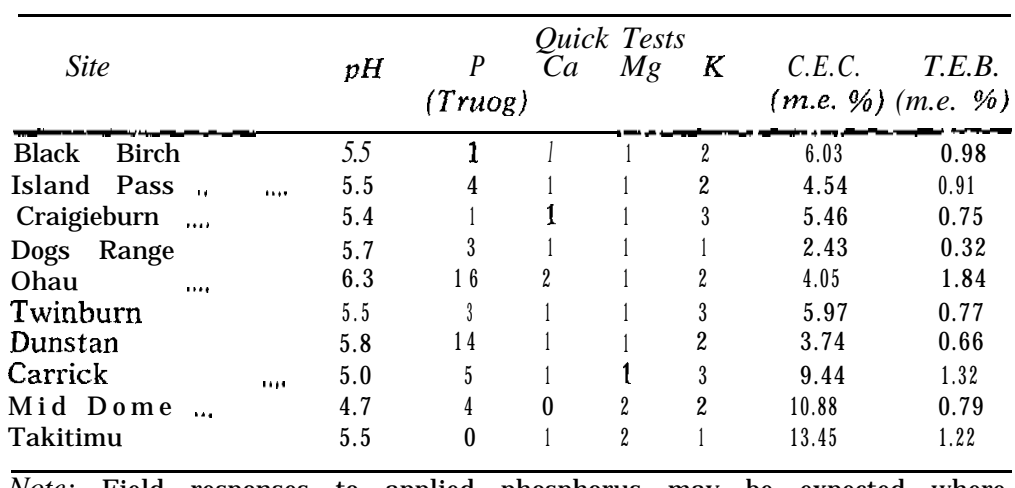

Note: Field responses to applied phosphorus may be expected where Truog $\mathrm{P}$ test is below 6. The quick test figures for available $\mathrm{Ca}, \mathrm{Mg}$ and $\mathrm{K}$ are all in the low to very low range (P. Gregg, pers. comm.).

Two pot trials were conducted at Lincoln between April 1966 and September 1967. Plant specie-s used were Massey Basyn Yorkshire fog (Holcus lanatus), and Huia white clover (Trifolium repens). Soils were air dried and passed through a $6 \mathrm{~mm}$ mesh sieve before potting in square section plastic pots having an exposed soil surface of approximately $120 \mathrm{~cm}^{2}$.

The nutrients used and the rates and forms in which they were applied are shown in Table 2. Lime was mixed well with the $9 \mathrm{~cm}$ depth of soil in each pot, $\mathrm{P}$ and $\mathrm{S}$ were applied to the surface as solids, and $\mathrm{N}, \mathrm{Mg}, \mathrm{K}, \mathrm{Cu}, \mathrm{B}, \mathrm{Zn}$ and Mo were applied to the surface in solution.

Trial design was as follows:

\section{Trial 1 - Winter 1966}

On 10 soils, Yorkshire fog and white clover were grown in separate sub-trials, each with five elements in a 32-pot, $2^{5}$ single replicate factorial design, giving a total of 640 pots. For Yorkshire fog, the five treatments were N, P, S, lime and "other elements" 
TABLE 2: FORMS AND RATES OF NUTRIENTS

\begin{tabular}{llccc}
\hline \multicolumn{2}{c}{ Element and Compound } & mg/pot & $\begin{array}{c}\text { Approx. } \\
\text { Rate of } \\
(\mathrm{kg} / \mathrm{ha})\end{array}$ & \\
\hline $\mathbf{N}$ & Ammonium nitrate & 500 & $\mathbf{N}$ & 138 \\
$\mathrm{P}$ & Monocalcium phosphate & 500 & $\mathbf{P}$ & 92 \\
$\mathrm{~S}$ & Calcium sulphate & 500 & $\mathbf{S}$ & 71 \\
$\mathrm{Mg}$ & Magnesium chloride & 250 & $\mathrm{Mg}$ & 30 \\
$\mathrm{~K}$ & Potassium chloride & 250 & $\mathrm{~K}$ & 99 \\
$\mathrm{CU}$ & Cupric chloride & 5 & $\mathrm{Cu}$ & 1.42 \\
$\mathrm{~B}$ & Borax & 10 & $\mathrm{~B}$ & 0.86 \\
$\mathrm{Zn}$ & Zinc acetate & 10 & $\mathrm{Zn}$ & 2.72 \\
$\mathrm{M} 0$ & Sodium molybdate & 0.3 & $\mathrm{M} \mathrm{0}$ & 0.09 \\
Lime & Calcium carbonate & 1250 & $\mathrm{CaCO}_{3}$ & 950 \\
\hline
\end{tabular}

Note: All materials analytical grade except for monocaicium phosphate.

(a mixture of $\mathrm{Mg}, \mathrm{K}, \mathrm{Cu}, \mathrm{B}, \mathrm{Zn}, \mathrm{Mo}$ ). For white clover the five treatments were $\mathrm{Mb}, \mathrm{P}, \mathrm{S}$, lime and "other elements" $(\mathrm{Mg}, \mathrm{K}$, $\mathrm{Cu}, \mathrm{B}, \mathrm{Zn})$.

Trial 2 - A. Summer 1966-7 (5 soils). B. Winter 1967 (5 soils)

On each soil, Yorkshire fog and white clover were grown in separate sub-trials, each with six elements in a 32-pot $2^{6}$ halfreplicate factorial design. For both Yorkshire fog and white clover, the six treatments were $\mathrm{Mg}, \mathrm{K}, \mathrm{Cu}, \mathrm{B}, \mathrm{Zn}$ and lime. In addition, basal treatments of $\mathrm{N}, \mathrm{P}, \mathrm{S}$ and Mo were applied to grass pots and $\mathrm{P}, \mathrm{S}$ and Mo to clover pots.

Pots were watered regularly with de-ionized water to $60 \%$ W.H.C. of each soil, by weight. There were four plants per pot in both trials. In Trial 1, Yorkshire fog was harvested after 15 weeks' and white clover after 17 weeks' growth. In Trial 2A, growth periods to harvest were: Yorkshire fog 9 weeks; white clover 12 weeks. In Trial $2 \mathrm{~B}$, growth periods to harvest were Yorkshire fog 13 weeks and white clover 15 weeks.

\section{RESULTS AND DISCUSSION}

YORKSHIRE FOG

In Trial 1, growth of Yorkshire fog was poor on all soils except when both nitrogen and phosphorus were applied (Table 3 ). Because of the magnitude of the NP interaction, the effect of the sulphur, lime and "other element" treatments could only be measured within the $\mathrm{N}+\mathrm{P}$ treatments. Thus apart from the strong NP X "other element" interaction as shown in Table 3, 
TABLE 3: NITROGEN AND PHOSPHORUS INTERACTION, AND YORKSHIRE FOG YIELD, TRIAL 1 (Mean weight in grams $\times 10^{-2}$ )

\begin{tabular}{|c|c|c|c|c|c|c|c|c|c|c|c|c|c|}
\hline & & & & $\begin{array}{l}\text { Black } \\
\text { Birch }\end{array}$ & $\begin{array}{c}\text { Island } \\
\text { Pass }\end{array}$ & Craigieburn & $\begin{array}{l}\text { Dogs } \\
\text { Range }\end{array}$ & Ohau & $\begin{array}{l}\text { Twin } \\
\text { burn }\end{array}$ & Dunstan & Carrick & $\begin{array}{c}\text { Mid } \\
\text { Dome }\end{array}$ & Takitimu \\
\hline$\overline{\mathrm{N}}, \mathrm{N}_{\mathrm{N}}^{\mathrm{N}} \mathrm{P}^{\mathrm{P}} \mathrm{P}$ & $\ldots$ & 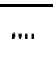 & $\ldots$ & 4 & 104 & 4 & 9 & 81 & 32 & 19 & 34 & 23 & 1 \\
\hline $\begin{array}{l}\text { No } \mathrm{N}, \mathrm{P} \\
\mathrm{N} \text { P }\end{array}$ & 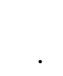 & . & $\cdots$ & $\begin{array}{r}19 \\
261\end{array}$ & $\begin{array}{r}16 \\
187\end{array}$ & $\begin{array}{r}11 \\
362\end{array}$ & $\begin{array}{r}14 \\
160\end{array}$ & $\begin{array}{r}9 \\
223\end{array}$ & $\begin{array}{r}42 \\
392\end{array}$ & $\begin{array}{r}12 \\
255\end{array}$ & $\begin{array}{r}32 \\
460\end{array}$ & $\begin{array}{r}35 \\
369\end{array}$ & $\begin{array}{r}17 \\
412\end{array}$ \\
\hline $1 \%$ LSD & $\ldots$ & & $\ldots$ & 15 & 62 & 44 & 46 & 62 & 34 & 72 & 43 & 36 & 40 \\
\hline $\begin{array}{l}\text { Significance } \\
\text { Significance } \\
\text { Int. }\end{array}$ & of $x$ & $\begin{array}{r}\text { int } \\
\times 0\end{array}$ & $\begin{array}{l}\text { eracti } \\
\text { ther }\end{array}$ & ion & $\begin{array}{l}\ldots \\
\ldots\end{array}$ & $* *$ & $\begin{array}{l}\text { ** } \\
* *\end{array}$ & $* *$ & ${ }^{* *}$ & *** & ${ }^{*}$ & $\begin{array}{l}* * * \\
*\end{array}$ & $\begin{array}{c}* * \\
*\end{array}$ \\
\hline
\end{tabular}


TABLE 4: DRY MATTER YIELD OF YORKSHIRE FOG, TRIAL 2
(Figures are differences in yield, in grams $\times 10^{-2}$, resulting from high and low rate of treatment)

\begin{tabular}{|c|c|c|c|c|c|c|c|c|c|c|}
\hline & \multicolumn{5}{|c|}{ A. Summer ${ }^{-} \overline{196}_{\overline{6}} \overline{\overline{7}}$} & \multicolumn{4}{|c|}{ B. Winter 1967} & \multirow[b]{2}{*}{$\begin{array}{l}\text { Mid } \\
\text { Dome }\end{array}$} \\
\hline & $\begin{array}{l}\text { Island } \\
\text { Pass }\end{array}$ & $\begin{array}{l}\text { D ogs } \\
\text { Range }\end{array}$ & Dunstan & Carsick & Takitimu & $\begin{array}{l}\text { Black } \\
\text { Birch }\end{array}$ & $\begin{array}{c}\text { Craigie- } \\
\text { burn }\end{array}$ & O hau & Twinburn & \\
\hline $\begin{array}{l}\text { Magnesium } \\
\text { Potassium } \\
\text { Copper } \\
\text { Boron } \\
\text { Zinc } \\
\text { Lime }\end{array}$ & $\begin{array}{c}122^{* *} \\
27^{* *} \\
-12^{*} \\
3 \\
12^{*} \\
-24^{* *}\end{array}$ & $\begin{array}{c}135^{* *} \\
9 \\
11 \\
19 \\
3 \\
-61 * *\end{array}$ & $\begin{array}{l}71^{* *} \\
26 \\
1 \\
-4 \\
4 \\
28\end{array}$ & $\begin{array}{c}117^{* *} \\
33 \\
-19 \\
-29 \\
-37 \\
53^{*}\end{array}$ & $\begin{array}{c}17^{*} \\
38^{* *} \\
24^{* *} \\
-12 \\
14 \\
-8\end{array}$ & $\begin{array}{c}153^{* *} \\
20 \\
-12 \\
-5 \\
-4 \\
8\end{array}$ & $\begin{array}{l}81^{*} \\
53^{* *} \\
-3 \\
-19 \\
-1 \\
-36^{* *}\end{array}$ & $\begin{array}{c}7 \\
-5 \\
-3 \\
-37^{* *} \\
17 \\
-21\end{array}$ & $\begin{array}{l}137^{* *} \\
-25^{*} \\
-23 \\
-32^{*} \\
4 \\
* \quad 16\end{array}$ & $\begin{array}{c}131 * * \\
-21 \\
3 \\
-16 \\
-5 \\
29 *\end{array}$ \\
\hline $\begin{array}{l}\text { Mean pot value } \\
\text { cv \% } \\
5 \% \text { LSD }\end{array}$ & $\begin{array}{l}87 \\
13.5 \\
9\end{array}$ & $\begin{array}{c}154 \\
18.3 \\
23\end{array}$ & $\begin{array}{c}288 \\
13.9 \\
32\end{array}$ & $\begin{array}{l}365 \\
17.1 \\
49\end{array}$ & $\begin{array}{c}347 \\
5.5 \\
15\end{array}$ & $\begin{array}{l}147 \\
18.3 \\
22\end{array}$ & $\begin{array}{c}222 \\
10.7 \\
19\end{array}$ & $\begin{array}{c}229 \\
10.5 \\
19\end{array}$ & $\begin{array}{l}232 \\
12.4 \\
23\end{array}$ & $\begin{array}{l}236 \\
13.5 \\
26\end{array}$ \\
\hline $1 \%$ Sig. interactions & $\begin{array}{l}\text { MgK } \\
\text { Lime }> \\
\text { Mg }\end{array}$ & $\begin{array}{l}\mathrm{MgK} \\
\times \operatorname{Lime}_{\mathrm{Mg}}\end{array}$ & $x^{\mathrm{MgK}}$ & & & MgK & MgK & & $\mathrm{MgK}$ & $\begin{array}{l}\mathrm{MgK} \\
\mathrm{MgCu}\end{array}$ \\
\hline
\end{tabular}


there was a significant NP $\times$ sulphur response on Black Birch, Mid Dome and Takitimu soils, and a significant NP $\mathbf{x}$ lime response on Black Birch and Mid Dome soils.

The effect of sulphur was not tested in Trial 2 because of the difficulty of avoiding contamination from atmospheric sulphur, but the effects of lime and the individual elements in the "other element" mixture are shown in Table 4.

In this trial magnesium significantly increased yield on nine soils, and there was positive response to potassium on seven. There were few positive effects from copper, boron or zinc. The main effect of lime was negative and significant or highly significant on four soils, and positive and significant on two. There was a strong magnesium $\times$ potassium interaction on seven of the ten soils. This is partly because potassium reduced yield where, applied without magnesium, but there is also a significant yield increase from the interaction on five soils (Table 6). The depressive effect of lime treatments on some soils, notably Dogs Range and Island Pass, appears to be through a reduction in $\mathrm{Mg}$ uptake because it was overcome by addition of magnesium.

\section{White Clover}

In Trial 1, clover did not grow in ten pots of Ohau soil, apparently because of inoculation failure in the free-draining scree material. Growth was variable in remaining pots and no conclusions were possible as to the effect of nutrient treatments. For the other nine soils, the effects of molybdenum, sulphur, lime and "other elements" were measured on phosphorus-treated pots only, since, in the absence of applied phosphorus, clover growth was insufficient for harvest on six soils, and was minimal on three.

In phosphorus-treated pots there was a positive significant response to molybdenum for Twinburn and Mid Dome soils, and a positive significant response to sulphur on Twinburn and Craigieburn. The effect of lime and "other elements" showed principally as a positive interaction on six soils, with the "other element" mixture giving significant benefits in the presence of lime.

Trial 2 showed that magnesium, potassium, copper, boron, zinc and lime had similar effects on clover as on Yorkshire fog (Table 5). There was a major positive main effect response to magnesium on six soils, but a major positive response to potassium on two soils only. Again, as for Yorkshire fog, there were few positive responses to copper, boron or zinc. Lime significantly depressed yield on three soils but significantly increased it on four, the trend 
TABLE 5: DRY MATTER YIELD OF WHITE CLOVER, TRIAL 2

(Figures are differences in yield, in grams $\times 10^{-2}$, resulting from high and low rates of treatment)

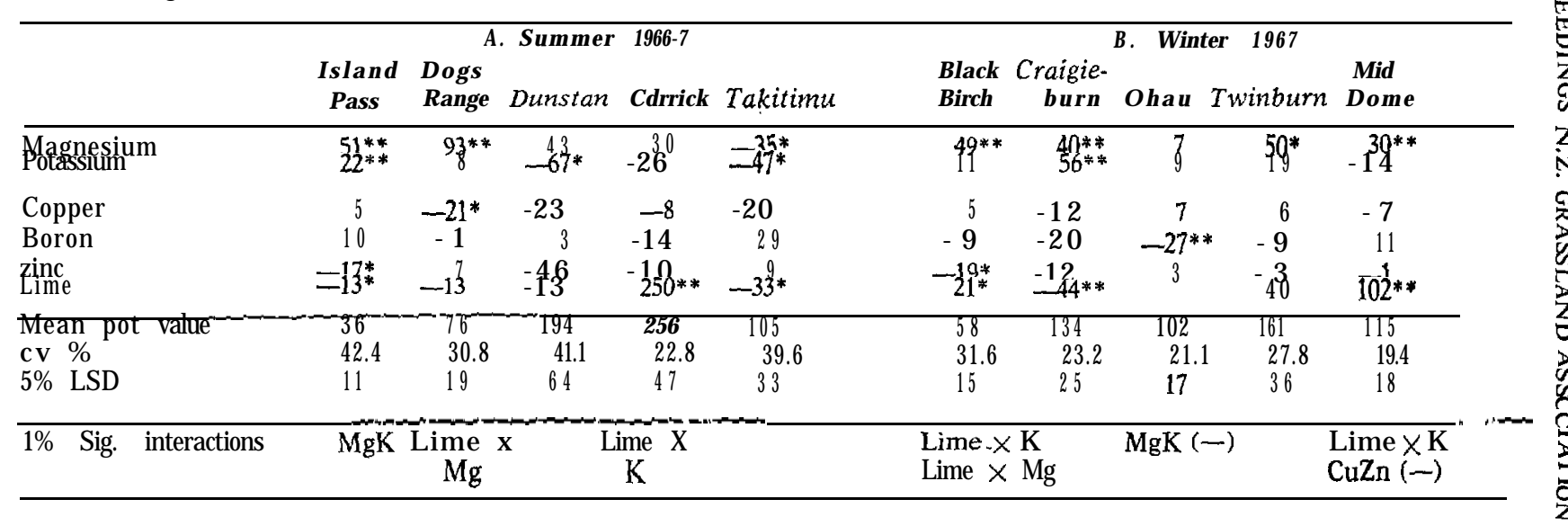


TABLE 6: $\mathrm{Mg} \times \mathrm{K}$ INTERACTIONS FOR YORKSHIRE FOG AND CLOVER, TRIAL 2 (Mean yield in grams $\times 10^{-2}$ )

\begin{tabular}{|c|c|c|c|c|c|c|c|c|c|c|}
\hline & $\begin{array}{c}\text { Island } \\
\text { Pass }\end{array}$ & $\begin{array}{l}\text { Dogs } \\
\text { Range }\end{array}$ & Dunstan & $\begin{array}{c}\text { orkshire } \\
\text { Black } \\
\text { Birch }\end{array}$ & $\begin{array}{l}\text { Fog } \\
\text { Craigie- } \\
\text { burn }\end{array}$ & Twinburn & $\begin{array}{l}\text { Mid } \\
\text { Dome }\end{array}$ & $\begin{array}{c}\text { Island } \\
\text { Pass }\end{array}$ & $\begin{array}{c}\text { hite C } \\
\text { Black } \\
\text { Birch }\end{array}$ & $\begin{array}{l}\text { ver } \\
\text { o hau }\end{array}$ \\
\hline No $\mathrm{Mg}$, No $\mathrm{K}$ & 39 & 109 & 268 & 94 & 177 & 195 & 204 & 12 & 49 & 81 \\
\hline No $\mathrm{Mg}, \mathrm{K}$ & 14 & 64 & 237 & 47 & 185 & 131 & 136 & 8 & 19 & 117 \\
\hline $\mathrm{Mg}, \mathrm{No} \mathrm{K}$ & 108 & 190 & 281 & 180 & 214 & 293 & 288 & 37 & 79 & 115 \\
\hline Me. $\mathrm{K}$ & 188 & 252 & 365 & 267 & 311 & 307 & 316 & 86 & 87 & 96 \\
\hline$\overline{5 \% ~ L S D}$ & 13 & 32 & 45 & 31 & 27 & 33 & 36 & $\overrightarrow{17}$ & 21 & 25 \\
\hline Trial mean & 87 & 154 & 288 & 147 & 222 & 232 & 236 & 36 & 58 & 102 \\
\hline $\begin{array}{l}\text { Significance of } \\
\text { interaction }\end{array}$ & ** & $* *$ & *** & $* *$ & ** & ** & *** & ** & $*$ & $* *$ \\
\hline
\end{tabular}


being for added benefit compared with Yorkshire fog on the most acid soils -e.g., Carrick and Mid Dome. The beneficial effect of a magnesium $\mathbf{x}$ potassium interaction was not so evident as with Yorkshire fog and was highly significant in Island Pass soil only (Table 6). However, observations and yield from individual pots suggest that the expression of the $\mathrm{MgK}$ interaction was inhibited on some soils by the low $\mathrm{pH}$ without lime.

\section{CONCLUSION}

This study provided a valuable guide to the fertilizer needs for successful revegetation of high-altitude subsoils. Phosphorus for clover growth, and nitrogen and phosphorus for grass were shown to be vital if plants are to grow sufficiently in one season to withstand severe winter frost-lift and damage. The responses to magnesium and potassium were so widespread as to warrant thorough field testing. Results from molybdenum and sulphur were inconclusive and there was little benefit from copper, boron and zinc. Further testing of lime was warranted, but its value would most likely be limited to strongly acid soils.

Field trials since conducted at the sites confirm in general the responses observed in these glasshouse trials.

\section{ACKNOWLEDGEMENTS}

'The authors are grateful to J. Barton, former technician, for assistance throughout the trials, to N. S. Mountier for the statistical design of Trial 2 and advice on analyses of the results, and to D. E. Hogg, Department of Agriculture, and H. Horn, Lincoln College, for soil quick test and soil exchange data, respectively. Assistance with soil collection by staff members of several catchment authorities and by W. 0. Sly, Ministry of Works, is also appreciated.

\section{REFERENCES}

Dunbar, G. A., 1970: Tussock Grassld Mount. Lands Inst. Rev., 18: 16-23. 1971: Proc. N.Z. ecol. Soc., 18: 48-57.

Holloway, J. T., 1970: Tussock Grassld Mount, Lands Inst. Rev., 18: 44-56. N.Z. Soil Bureau, 1968: Soil Bur. Bull., 27.

O'Connor, K. F., 1967: Soil and Water, 4 (1): 3-6.

O'Connor, K. F., Lambrechtsen, N. C., 1967: Proc. N.Z. ecol. Soc., 14: 1-7. 